\title{
Biochemical and biological evaluation of gyroxin isolated from Crotalus durissus terrificus venom
}

Barros LC (1, 2), Soares AM (3), Costa FL (4), Rodrigues VM (4), Fuly AL (5), Giglio JR (6), Gallacci M (7), Thomazini-Santos IA (1), Barraviera SRCS $(2,8)$, Barraviera B (1, 2), Ferreira Junior RS $(1,2)$

(1) Department of Tropical Diseases and Imaging Diagnosis, Botucatu Medical School, São Paulo State University (UNESP Univ Estadual Paulista), Botucatu, São Paulo State, Brazil; (2) Center for the Study of Venoms and Venomous Animals, São Paulo State University (UNESP - Univ Estadual Paulista), Botucatu, São Paulo State, Brazil; (3) Department of Clinical, Toxicological and Bromatological Analysis, School of Pharmaceutical Sciences, University of São Paulo, USP, Ribeirão Preto, São Paulo State, Brazil; (4) Institute of Genetics and Biochemistry, Federal University of Uberlândia, Uberlândia, Minas Gerais State, Brazil; (5) Department of Cellular and Molecular Biology, Institute of Biology, Fluminense Federal University, UFF, Niterói, Rio de Janeiro State, Brazil; (6) Department of Biochemistry and Immunology, Medical School of Ribeirão Preto, University of São Paulo, USP, Ribeirão Preto, São Paulo State, Brazil; (7) Department of Pharmacology, Institute of Biology, São Paulo State University (UNESP - Univ Estadual Paulista), Botucatu, São Paulo State, Brazil; (8) Department of Dermatology, Botucatu Medical School, São Paulo State University (UNESP - Univ Estadual Paulista), Botucatu, São Paulo State, Brazil.

\begin{abstract}
Gyroxin, a thrombin-like enzyme isolated from Crotalus durissus terrificus venom and capable of converting fibrinogen into fibrin, presents coagulant and neurotoxic activities. The aim of the present study was to evaluate such coagulant and toxic properties. Gyroxin was isolated using only two chromatographic steps - namely gel filtration (Sephadex G-75) and affinity (Benzamidine Sepharose 6B) - resulting in a sample of high purity, as evaluated by RP-HPLC C2/C18 and electrophoretic analysis that showed a molecular mass of $30 \mathrm{kDa}$. Gyroxin hydrolyzed specific chromogenic substrates, which caused it to be classified as a serine proteinase and thrombin-like enzyme. It was stable from pH 5.5 to 8.5 and inhibited by $\mathrm{Mn}^{2}+, \mathrm{Cu}^{2}+$, PMSF and benzamidine. Human plasma coagulation was more efficient at $\mathrm{pH}$ 6.0. An in vivo toxicity test showed that only behavioral alterations occurred, with no barrel rotation. Gyroxin was not able to block neuromuscular contraction in vitro, which suggests that its action, at the studied concentrations, has no effect on the peripheral nervous system.
\end{abstract}

Key words: gyroxin, neurotoxicity, coagulant activity, Crotalus durissus terrificus, serine proteinase.

\section{INTRODUCTION}

The active components of snake venom can be used as important tools to elucidate many pharmacological mechanisms including neuromuscular junction transmission, blood coagulation cascade, fibrinolysis, complement system and inflammatory processes $(1,2)$. Among snake venom proteins, metalloproteinases and serine proteinases are responsible for blood hemodynamic alterations (clot formation and clot dissolution) $(3,4)$.

Serine proteinases are abundant, especially in Viperidae venoms, in which they account for about $20 \%$ of the total protein content $(5,6)$. These enzymes display in vitro coagulant activity and are often referred to as thrombin-like enzymes, since their function resembles that of the best known of human and animal thrombin, namely the ability to cleave fibrinogen into fibrin, leading to clot formation $(7,6)$. Snake venom thrombinlike enzymes (SVTLEs) can act by cleaving both chains of fibrinogen, $A \alpha$ and $B \beta$, releasing fibrinopeptides A (FpA) and/or fibrinopeptides B (FpB) $(2,5)$.

Gyroxin belongs to the thrombin-like group and was isolated from the venom of Crotalus durissus terrificus by Raw et al. (8) in 1986 using three chromatographic steps of purification (ammonium sulfate precipitation, Sephadex G-75 and Sepharose-1,4 butanediol-diglycyl-paminobenzamidine). The electrophoretic analysis 
showed a mass of $34 \mathrm{kDa}$ and an optimum $\mathrm{pH}$ for human blood coagulation of 8.0 (8).

Besides acting on coagulation, gyroxin presents an outstanding neurotoxic activity causing a syndrome called "barrel rotation". This syndrome was observed for the first time by Barrio (9) in 1961, who described the effects of gyroxin isolated from the Crotalus durissus terrificus venom.

This enzyme can be an interesting molecular model for the development of drugs or therapeutic agents (10-12), mainly due to its resistance to physiological proteinase inhibitors $(2,3)$. In the present study, we described a two-step isolation and biochemical/biological characterization of gyroxin from Crotalus durissus terrificus venom.

\section{MATERIALS AND METHODS}

\section{Materials}

Crotalus durissus terrificus snake venom, vacuum dried and stored at $4^{\circ} \mathrm{C}$, was obtained from specimens kept in the serpentarium of the Center for the Studies of Venoms and Venomous Animals (CEVAP), São Paulo state, Brazil. Sephadex G-75, Benzamidine Sepharose 6B, C2/ C18 column for RP/HPLC and molecular weight markers were purchased from Amersham Life Science Inc (Sweden). The H-D-Phe-pipecolylArg-pNA.2HCl (S-2238) and H-D-Ile-ProArg-pNA.2HCl (S-2288) substrates came from Chromogenix (Italy). All other reagents used for chemical and biological characterization were of analytical grade and purchased from Sigma Chemical Co (USA). The plasma was obtained from healthy donors, aged between 18 and 42 years, kindly provided by the Botucatu Medical School Blood Bank, São Paulo, Brazil.

\section{Animals}

Swiss mice were obtained from the Botucatu Medical School Animal Facility (São Paulo state, Brazil) and maintained under standard conditions (temperature $22 \pm 1^{\circ} \mathrm{C}$, relative humidity $60 \pm 5 \%$, 12-hour light/dark cycle) with food and water ad libitum. The experimentation protocol was approved by the Ethics Committee on Animal Experimentation of the Botucatu Medical School, São Paulo State University, São Paulo state, Brazil (protocol number 657-2008) and is in agreement with the ethical principles of animal experimentation adopted by the Brazilian Society of Science for Laboratory Animals.

\section{Gyroxin Isolation}

Crotalus durissus terrificus crude venom (1 g) was applied to a Sephadex G-75 column (110 $\mathrm{x} 4.0 \mathrm{~cm}$ ), previously equilibrated with $0.05 \mathrm{M}$ ammonium formiate, $\mathrm{pH}$ 3.5. Elution was carried out using the same buffer at a flow rate of $30 \mathrm{~mL} /$ hour, collecting $1 \mathrm{~mL} /$ tube. The fraction showing clotting activity was applied to a Benzamidine Sepharose $6 \mathrm{~B}$ column $(8.5 \times 2.5 \mathrm{~cm})$ previously equilibrated with $0.05 \mathrm{M}$ Tris- $\mathrm{HCl}$ buffer, $\mathrm{pH}$ 7.4. Elution started at room temperature, with $30 \mathrm{~mL}$ of the same buffer containing $0.5 \mathrm{M} \mathrm{NaCl}$ followed by $20 \mathrm{~mL}$ of glicine ( $0.02 \mathrm{M}, \mathrm{pH} 3.2)$, and it was ended by adding $400 \mu \mathrm{L}$ Tris- $\mathrm{HCl}(1.0 \mathrm{M}$, $\mathrm{pH}$ 9.0). The flow rate was $30 \mathrm{~mL} /$ hour, collecting $3 \mathrm{~mL} /$ tube.

The active fraction was concentrated by ultrafiltration in an Amicon YM10 System (Millipore, USA) and then applied to reverse phase HPLC using a C2/C18 column of $2.0 \times 25$ $\mathrm{cm}$ (Shimadzu, Japan), which was equilibrated with solvent A ( $0.1 \%$ trifluoroacetic acid) and eluted with a concentration gradient of solvent $\mathrm{B}$ (70\% acetonitrile) from 0 to $100 \%$ at a flow rate of $1 \mathrm{~mL} /$ minute at room temperature.

\section{Biochemical Characterization}

\section{Determination of relative molecular mass ( $\mathrm{Mr}$ )}

The $13.5 \%$ SDS-polyacrylamide gel electrophoresis (SDS-PAGE) was performed according to Laemmli (13). Samples were heated at $70^{\circ} \mathrm{C}$ for five minutes and then run under reducing conditions (SDS $+10 \%$ $\beta$-mercaptoethanol). The gel was stained with Coomassie brilliant blue R-250 (Pharmacia Biotech, USA). Mr was estimated by interpolation from a linear logarithmic plot of relative molecular mass versus distance of migration. The molecular mass markers used were: bovine serum albumin $(66 \mathrm{kDa})$, ovalbumin $(45 \mathrm{kDa})$, glyceraldehyde3-phosphate dehydrogenase $(36 \mathrm{kDa})$, carbonic anhydrase $(29 \mathrm{kDa})$, trypsinogen $(24 \mathrm{kDa})$, trypsin inhibitor $(20.1 \mathrm{kDa})$ and $\alpha$-lactalbumin (14.4 kDa) (Amersham Biosciences).

\section{Isoelectric focusing}

The $\mathrm{pI}$ of the isolated protein was determined according to the method previously described by 
Vesterberg (14) with some modifications. A 7\% polyacrylamide gel with ampholine at $\mathrm{pH} 3.0$ to 10.0 was used in a preliminary run for 30 minutes at $500 \mathrm{~V}$. After this, a $1-\mathrm{mg} / \mathrm{mL}$ sample of enzyme $(10 \mu \mathrm{L})$ in aqueous solution with $10 \%$ glycerol was poured into the gel. Isoelectric focusing markers $(\beta$-lactaglobulin, carbonic anhydrase and trypsinogen) were run parallel to the sample for five hours at $1500 \mathrm{~V}$. Two strips were used to connect the gel and the platinum electrodes, with cathode in $1 \mathrm{M} \mathrm{NaOH}$ and anode in $1 \mathrm{M}$ phosphoric acid. The experiments were carried out at $4^{\circ} \mathrm{C}$ and the pI bands were detected by silver staining (Pharmacia Biotech, USA).

\section{$\mathrm{N}$-terminal sequencing}

The N-terminal sequence of enzyme was determined using Shimadzu PPSQ-23A (Japan) automatic protein sequencer based on Edman degradation (15), using a solution with approximately $1 \mathrm{mg} / \mathrm{mL}$ of the purified enzyme. The sequence and homology of the amino acids were analyzed by alignment using the BLAST program (blast.ncbi.nlm.nih.gov) (16) and compared with four other sequences of serine proteinases present in the National Center for Biotechnology Information (NCBI): gyroxin analog from Lachesis muta muta; ancrod from Agkistrodon rhodostoma; crotalase from Crotalus adamanteus and gyroxin from Crotalus durissus terrificus.

\section{Enzymatic Characterization}

\section{Hydrolytic activity upon synthetic substrates}

The ability of gyroxin to hydrolyze chromogenic substrates S-2238 (for thrombin-like enzymes) and S-2288 (for serine proteinase) $(0.5 \mathrm{mM}$, final concentration) was tested in a Thermomax Microplate reader (Molecular Devides, USA) monitored at $450 \mathrm{~nm}$ for 20 minutes at $37^{\circ} \mathrm{C}$. When indicated, divalent ions $\left(\mathrm{Ca}^{2}+, \mathrm{Ba}^{2}+, \mathrm{Mn}^{2}+\right.$ and $\mathrm{Cu}^{2}+$ ), inhibitors (20 mM EDTA and 10 $\mathrm{mM}$ 1,10-phenanthroline which are specific to metalloproteases or $20 \mathrm{mM}$ PMSF and $150 \mathrm{mM}$ benzamidine specific to serine proteinases) as well as buffers at different $\mathrm{pH}$ values $(3.5,4.5$, $5.5,6.8,7.5,8.5,11$ and 13) were preincubated for 20 minutes at $37^{\circ} \mathrm{C}$ with gyroxin, and then the enzymatic reaction was assayed with a chromogenic substrate, S-2238 (17).

\section{Clotting activity upon human plasma}

The clotting time was determined by mixing $100 \mu \mathrm{L}$ of the samples (in MilliQ water, $\mathrm{pH} 4.0$, 6.0 and 7.4) with $200 \mu \mathrm{L}$ of citrated human plasma at $37^{\circ} \mathrm{C}$. Different amounts of the enzyme (3.0 to $25.0 \mu \mathrm{g}$ ) were also assayed in order to determine the minimum coagulant dose (MCD), which indicates the smallest amount of enzyme able to completely coagulate citrated human plasma in 60 seconds (18). Each dose was assayed in triplicate. The maximum period for observation of clot formations was five minutes.

\section{Biological Activities}

\section{In vivo toxicity test}

The in vivo test was performed using Swiss mice, injected with test samples at 0.1 to $0.6 \mu \mathrm{g} / \mathrm{g}$ body weight by intraperitoneal injection and observed for 60 minutes. Barrel rotation or other symptoms should appear spontaneously in this period. A typical barrel rotation consisted of at least one full rotation over the long axis of the body, performed in one second or less (19).

\section{Neuromuscular blocking activity (in vitro toxicity test)}

Mice were euthanized by exsanguination after choral hydrate anesthesia. Phrenic-diaphragm (PD) preparation was removed according to Bülbring (20), and mounted vertically in a conventional isolated organ-bath chamber containing $10 \mathrm{~mL}$ of physiological solution of the following composition (mmol/L): $\mathrm{NaCl}$, 135; $\mathrm{KCl}, 5 ; \mathrm{MgCl}_{2}, 1 ; \mathrm{CaCl}_{2}, 2 ; \mathrm{NaHCO}_{3}, 15$; $\mathrm{Na}_{2} \mathrm{HPO}_{4}$, 1; glucose, 11. This solution was bubbled with carbogen $\left(95 \% \mathrm{O}_{2}\right.$ and $\left.5 \% \mathrm{CO}_{2}\right)$. The preparation was attached to an isometric force transducer (Grass, FT03) to record the twitch tension. The transducer signal output was amplified and recorded on a computer via a transducer signal conditioner (Gould, 136615-50) with an AcquireLab Data Acquisition System (Gould, USA). The resting tension was $5 \mathrm{~g}$. Indirect contractions were evoked by supramaximal pulses $(0.2 \mathrm{~Hz}, 0.5 \mathrm{~ms})$ delivered from an electronic stimulator (Grass-S88K) and applied to the phrenic nerve by means of a suction electrode. The preparation was allowed to stabilize for 45 minutes before the addition of enzyme ( 25 and $40 \mu \mathrm{g} / \mathrm{mL}$ ). Control experiments were performed in the absence of enzyme. 


\section{Statistical Analysis}

All data are presented as means \pm SE. Data were analyzed using analysis of variance (ANOVA) to evaluate the statistical differences among groups. In all cases, the significance level was considered to be $\mathrm{p}<0.05$. Minimal coagulant doses (MCD) were calculated using potential regression analysis $\left(y=A \cdot x^{-B}\right)$.

\section{RESULTS}

\section{Isolation and Biochemical Characterization}

Fractionation by Sephadex produced four major protein peaks (Figure $1-\mathrm{A}$ ), denominated S1 to S4. Only S2 showed clotting activity. After lyophilization, S2 was submitted to another chromatographic step on Benzamidine Sepharose 6B which yielded three new fractions, named BS1 to BS3 (Figure 1-B). Fraction BS3 (gyroxin) showed in vitro coagulant activity upon human plasma and was analyzed by reverse-phase HPLC chromatography (Figure $1-\mathrm{C})$.

This protein fraction consisted of an apparent single polypeptide chain presenting a molecular mass of approximately $30 \mathrm{kDa}$ in SDS-PAGE under reducing conditions (Figure $1-\mathrm{D}$ ) and $\mathrm{pI}$ $\sim 5.5$ (Figure $1-\mathrm{E}$ ).
The sequence of the first 20 amino acid residues from the $\mathrm{N}$-terminal region of gyroxin showed high similarity with other thrombin-like serine proteinases and a 100\% similarity with the gyroxin of Crotalus durissus terrificus stored in the data bank (Table 1).

From these results, the serine proteinase isolated and purified from Crotalus durissus terrificus venom was identified as gyroxin.

\section{Functional Characterization}

Gyroxin was able to hydrolyze both S-2238 and S-2288 chromogenic substrates in a concentration-dependent manner (Figure 2 - A). Both substrates are regularly used for thrombin-like or serine proteases, respectively. Gyroxin's enzymatic activity upon S-2238 was inhibited by PMSF and benzamidine, while EDTA or 1,10-phenanthroline did not abolish its activity (Figure $2-\mathrm{B}$ ). Moreover, the activity of gyroxin was higher at $\mathrm{pH}$ values from 7.5 to 8.5 (Figure $2-\mathrm{C}$ ). At $\mathrm{pH}$ values of $3.5,4.5$ and 13 no activity on S-2238 was detected (Figure 2 - C). We also assayed the influence of different divalent ions on hydrolysis of S-2238 induced by gyroxin. As shown in Figure $2-\mathrm{D}$, no activity was observed in the presece of $\mathrm{Mn}^{2+}$ or $\mathrm{Cu}^{2+}$, but addition of $\mathrm{Ca}^{2+}$ fully restored gyroxin's activity

Table 1. Comparison of the $\mathrm{N}$-terminal amino acid sequence of gyroxin with other snake venom serine proteinases

\begin{tabular}{c|c|c|c|c}
\hline Enzyme & Snake species & N-terminal amino acid sequence & $\begin{array}{c}\text { NCBI } \\
\text { access } \\
\text { code }\end{array}$ & References \\
\hline Gyroxin & $\begin{array}{c}\text { Crotalus } \\
\text { durissus } \\
\text { terrificus }\end{array}$ & VIGGDECNINEHRFLVALYE & Present study \\
\hline Gyroxin analog & $\begin{array}{c}\text { Lachesis muta } \\
\text { muta }\end{array}$ & VIGGDECNINEHRFLVALYD & gi: 464885 & 21 \\
\hline Crotalase & $\begin{array}{c}\text { Agkistrodon } \\
\text { rhodostoma }\end{array}$ & VIGGDECNINEHRFLVALYD & gi: 113827 & 22 \\
\hline Grotalus & VIGGDECNINEHRFLVALYD & gi: 250562 & 23 \\
\hline Gyroxin & $\begin{array}{c}\text { Crotalus } \\
\text { durissus } \\
\text { terrificus }\end{array}$ & VIGGDECNINEHRFLVALYE & 61741494 & 24 \\
\hline
\end{tabular}



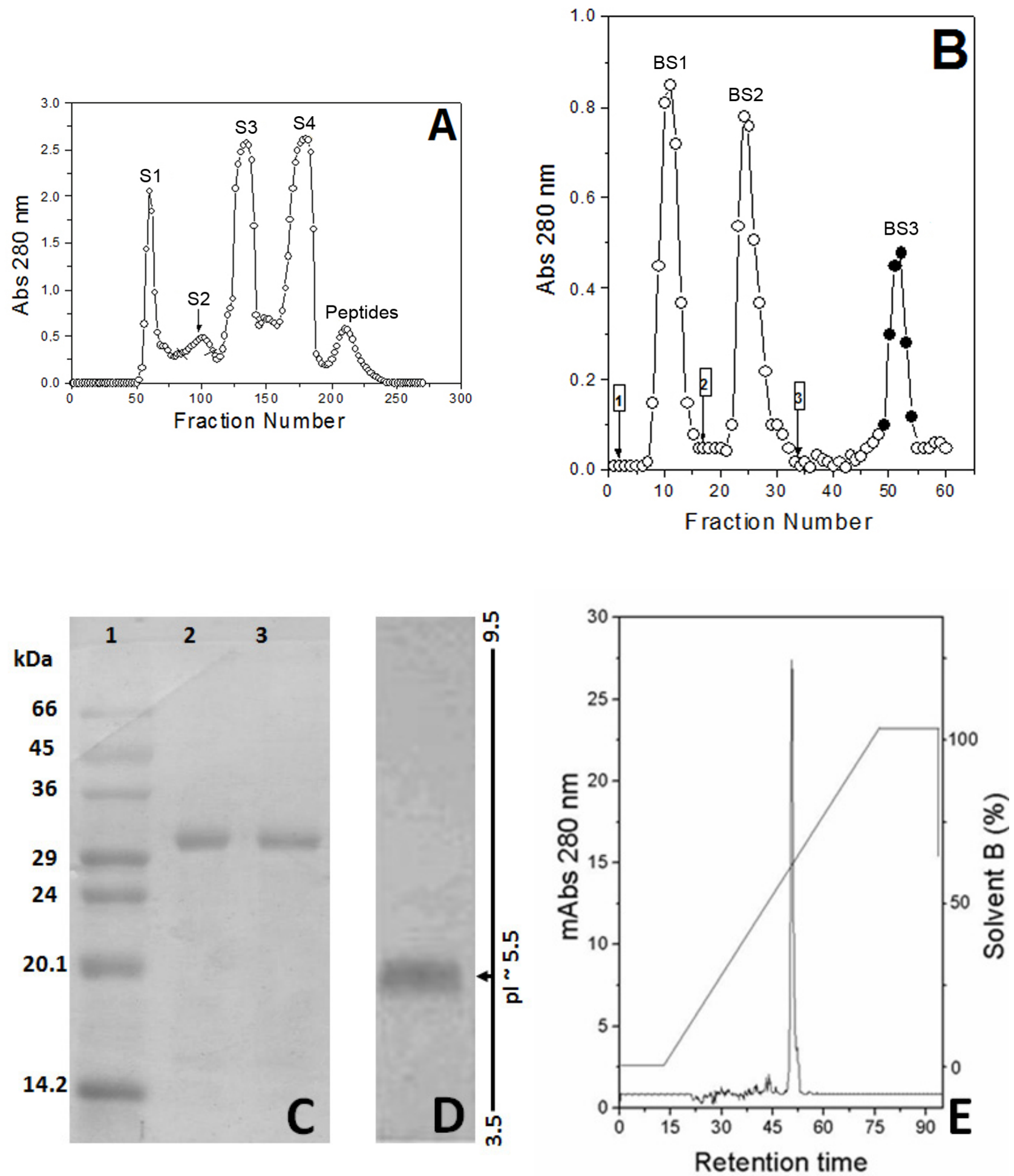

Figure 1. Sequential purification steps of gyroxin. (A) Crotalus durissus terrificus venom (1 g) on Sephadex $\mathrm{G}-75$, in $0.05 \mathrm{M}$ ammonium formate buffer, $\mathrm{pH}$ 3.5. Fractions of $10 \mathrm{~mL} /$ tube were collected at a flow rate of $30 \mathrm{~mL} /$ hour. (B) The active coagulant fraction, denominated S2 $(100 \mathrm{mg})$, was rechromatographed on a Benzamidine Sepharose $6 \mathrm{~B}$ column $(8.5 \times 2.5 \mathrm{~cm})$ previously equilibrated with $0.05 \mathrm{M}$ Tris $-\mathrm{HCl}$, pH 7.4 plus $\mathrm{NaCl} 0.5 \mathrm{M}$ (solvent $A$ ) at room temperature and then eluted with $20 \mathrm{~mL}$ of glycine $0.02 \mathrm{M}, \mathrm{pH} 3.2$ (solvent B), ending up with $400 \mu \mathrm{L}$ of Tris-HCl $1.0 \mathrm{M} \mathrm{pH}$ 9.0. (C) Analysis of BS3 (gyroxin) by RP-HPLC using a C2/C18 column of $4.6 \times 100 \mathrm{~mm}$ (Shimadzu, Japan), equilibrated with solvent A (0.1\% trifluoroacetic acid and $5 \%$ acetonitrile) and eluted with a concentration gradient of solvent $B(60 \%$ acetonitrile, $0.1 \%$ trifluoroacetic acid) from 0 to $100 \%$ at a flow rate of $1 \mathrm{~mL} /$ minute at room temperature. (D) SDSPAGE (13.5\%) of gyroxin. Lanes: (1) molecular mass markers, (2 and 3) purified gyroxin. (E) pl determination for gyroxin, pl 5.5. 

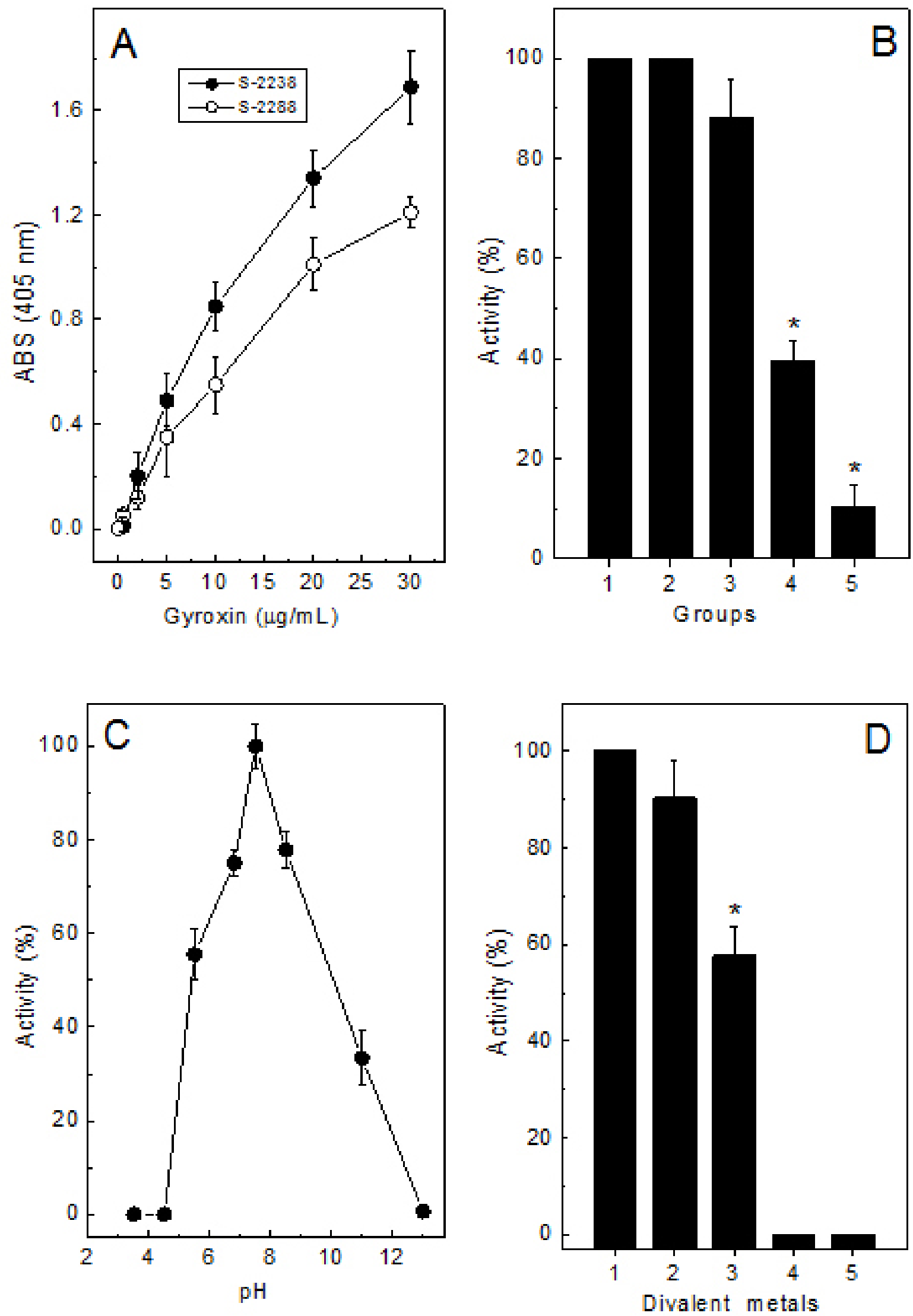

Figure 2. Gyroxin activity upon synthetic substrates $(0.5 \mathrm{mM})$. (A) Concentration-dependent hydrolysis of S-2238 and S-2288. (B) Effect of inhibitors; groups: no inhibitor (column 1); 20 mM EDTA (column 2); $10 \mathrm{mM}$ 1,10-phenanthroline (column 3); 20 mM PMSF (column 4) or $150 \mathrm{mM}$ benzamidine (column 5). (C) Effect of $\mathrm{pH}(3.5,4.5,5.5,6.8,7.5,8.5,11$ and 13) and (D) effect of $10 \mathrm{mM}$ divalent metals: without adding any ion (column 1); $\mathrm{Ca}^{2+}$ (column 2); $\mathrm{Ba}^{2+}$ (column 3); $\mathrm{Mn}^{2+}$ (column 4); $\mathrm{Cu}^{2+}$ (column 5) on the hydrolysis of S-2238 induced by $20 \mu \mathrm{g} / \mathrm{mL}$ gyroxin after a 10 -minute reaction at $37^{\circ} \mathrm{C}$. Data are expressed as means \pm SD of two individual experiments $(n=3)$. Asterisks $\left(^{*}\right)$ represent significance $(p<0.05)$ compared to column 1 . 


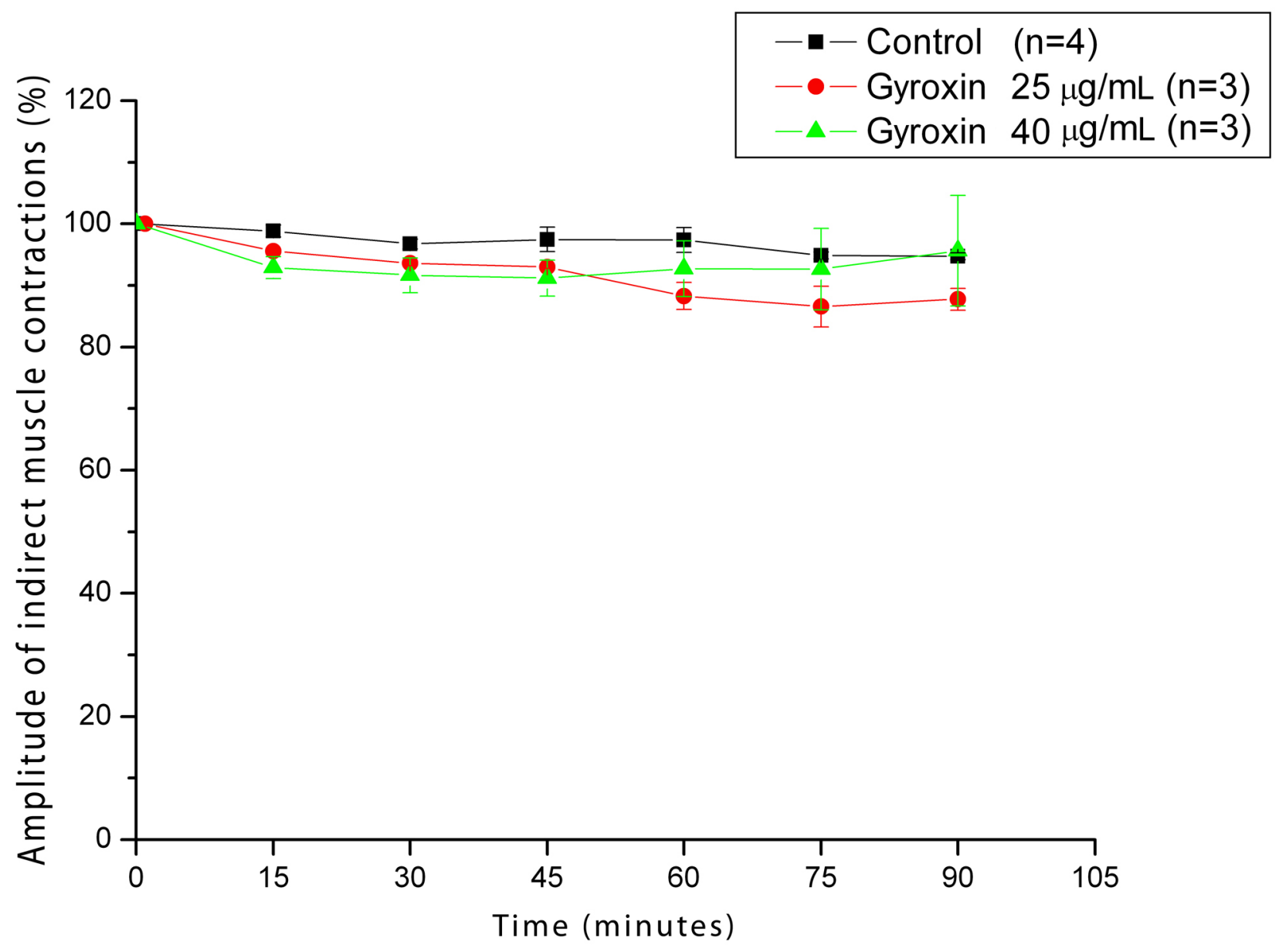

Figure 3. Effects of gyroxin on indirectly evoked twitches in mouse phrenic-diaphragm preparations. The ordinate represents the amplitude percentage (\%) of twitches relative to the initial amplitude. The abscissa indicates the time (minutes) after the addition of gyroxin to the organ bath. The results indicate no significant differences produced by gyroxin at $25 \mu \mathrm{g} / \mathrm{mL}$ or gyroxin at $40 \mu \mathrm{g} / \mathrm{mL}$ in relation to control ( $p$ $\leq 0.05)$.

on that chromogenic substrate. In parallel, the addition of $\mathrm{Ba}^{2+}$ was also unable to restore such gyroxin activity (Figure $2-\mathrm{D}$ ).

Gyroxin showed a high clotting activity upon human plasma with $\mathrm{MCD}=0.037 \mu \mathrm{g} / \mu \mathrm{L}(\mathrm{pH}$ 4.0), $0.015 \mu \mathrm{g} / \mu \mathrm{L}(\mathrm{pH} 6.0)$, and $0.021 \mu \mathrm{g} / \mu \mathrm{L}(\mathrm{pH}$ 7.4).

The barrel rotation was not observed but other behavioral effects were registered such as periods of hyperexcitation and running followed by tachypnea, immobility, stretching of posterior limbs and grooming behavior. The animals recovered in one hour after the injection and after 24 hours the picture was asymptomatic. Gyroxin did not induce the blockade of twitch evoked indirectly in mouse phrenic-diaphragm preparation as illustrated in Figure 3.

\section{DISCUSSION}

The most employed techniques for the isolation and purification of thrombin-like enzymes have been gel filtration followed by affinity chromatographic steps with few modifications, in the pursuit of ideal conditions for better resolution and yield $(25,26)$.

To isolate the gyroxin by gel filtration, the Sephadex G-75 column at a low pH (ammonium formiate $\mathrm{pH}$ 3.5) was used which, besides maintaining the integrity of fractions and thus preventing their degradation, promoted a better separation resulting in four distinct peaks, in agreement with other authors who also showed four peaks using the same process $(27,28)$. Peak II showed coagulant and esterasic activities, and was submitted to affinity chromatography 
on Benzamidine Sepharose 6B. Using elution at different pHs (buffer $2 \mathrm{pH} 7.4$ and buffer $3 \mathrm{pH}$ 3.2 ), this step resulted in three distinct peaks and the enzyme of interest was located in the third and lowest peak after elution with glycine.

Differing from these results, Raw et al. (8) showed only two peaks resulting from an affinity chromatography on Sepharose-1,4 butanedioldiglycyl-p-aminobenzamidine, and the second and lower peak, after elution with benzamidine, demonstrated thrombin-like activity. Alexander et al. (25), in 1988, using affinity chromatography on Benzamidine Sepharose 6B found two peaks after elution with benzamidine, verifying that only the second and lower peak showed thrombin-like coagulant activity, characteristic of gyroxin.

The molecular mass of Crotalus durissus terrificus gyroxin has been estimated by several authors as being between 29 and $36 \mathrm{kDa}$ (25, 29). According to electrophoretic analysis in denaturing conditions, the gyroxin isolated in this study revealed a molecular mass of $\sim 30 \mathrm{kDa}$. This result corroborates recent studies realized by De Oliveira et al. (30). The pI value of the purified serine proteinase was 5.5 indicating an acidic characteristic to the protein, agreeing with studies that indicate a variable pI between 4.6 and 6.6 for serine proteinases (31).

Since the gyroxin was highly enriched, as determined by SDS-PAGE, further assessment of gyroxin purity was conducted by reverse-phase HPLC using a C2/C18 column that showed a single peak.

$\mathrm{N}$-terminal sequence has been utilized to show similarity and identity with protein isolated by other authors and already characterized. In this study, the isolated and purified protein exhibited almost $100 \%$ similarity to other thrombin-like enzymes previously characterized by analysis of the first 20 amino acid residues, suggesting a common molecular ancestry. This high homology among the coagulant enzymes is confirmed by the presence of valine $(\mathrm{V})$ as the first N-terminal residue, a common feature of most SVTLEs (32), enabling the classification of the isolated serine proteinase as gyroxin.

Gyroxin catalyzed the hydrolysis of the chromogenic substrates S-2238 and S-2288, thus demonstrating itself to be a serine proteinase that belongs to the thrombin-like enzyme group. These peptides H-D-Phe-pipecolyl-Arg-pNA.2 HCl (S2238) and H-D-Ile-pro-Arg-pNA.2HCl (S-2288) are the substrates most susceptible to hydrolysis by gyroxin, since their active centers have an anionic nature that requires high specificity and preference for amino acid residues such as arginine (33).

Benzamidine efficiently inhibited the activity of the enzyme upon S-2238 substrate, in contrast to a partial inhibition when PMSF was used because it is classified as a serine proteinase inhibitor. The PMFS has the ability to bind irreversibly to the serine residue at the catalytic site leading to the inactivation of the protein. These data were confirmed by studies carried out with a thrombin-like enzyme, known as BpSP-I, isolated from the venom of Bothrops pauloensis (34).

Gyroxin showed a high stability in maintaining normal activity upon S-2238 substrate when incubated at different pHs (7.5 to 8.5); however, at low (3.5 to 4.5) and high (over 13.0) pHs, the enzyme lost its activity. This feature was similar to that of calobin II, isolated from the venom of Agkistrodon caliginosus, which presented an optimum $\mathrm{pH}$ of 8.0 but was drastically affected at pHs below 6.0 and over 10.0 (35).

In the presence of $\mathrm{Ca}^{2+}$, the gyroxin activity was stable. It was also observed that in the presence of $\mathrm{Mn}^{2+}$ and $\mathrm{Cu}^{2+}$, the activity was inhibited. Based on these data, it was suggested that these ions provoke some direct or indirect conformational changes at the protein catalytic site that decrease its efficiency (36).

In contrast, the serine proteinases present in vitro coagulant activity upon human plasma, a characteristic of gyroxin $(8,25)$. In the present study, gyroxin showed a high level of coagulant activity with a minimal coagulant dose of 0.037 to $0.015 \mu \mathrm{g} / \mu \mathrm{L}$ when compared with data of De Oliveira et al. (30), who found a minimal coagulant dose of $1.5 \mu \mathrm{g} / \mu \mathrm{L}$. It was stable across a large $\mathrm{pH}$ range, while its action upon human plasma was observed between 6.0 and 7.4, similar to thrombin's optimum $\mathrm{pH}$ (7.3).

The in vivo toxicity evaluation of gyroxin revealed some behavioral effects on mice including: initial hyperexcitation and running followed by tachypnea, immobility, stretching of posterior limbs and grooming behavior, corroborating previous results in the literature (37). However, Camillo et al. (29) observed the barrel rotation, described by Barrio (9), when the gyroxin was intravenously administrated at a dose 
of $0.25 \mu \mathrm{g} / \mathrm{g}$. We did not observe this symptom in the current study, even when inoculated intraperitoneally at $0.6 \mu \mathrm{g} / \mathrm{g}$. However, some authors suggest that the barrel rotation syndrome is a special consequence of the intravenous administration of some viperid snake venoms $(25,29,38)$.

Most neurotoxins show an effect on the peripheral nervous system, due to the fact that they do not cross the blood-brain barrier. However the action of venom and toxins on neuromuscular junction has not been elucidated. Snakes have developed the capacity to produce potent toxins able to inhibit the pre- and postsynaptic neuromuscular transmission at specific sites (39).

To verify the gyroxin effect upon the peripheral nervous system, the alterations in muscular twitches were analyzed. This evaluation was made from mouse phrenic-diaphragm preparation. The neuromuscular blockade was not observed suggesting that, at the concentrations utilized, gyroxin has no effect on the peripheral nervous system. Studies realized with crotoxin and gyroxin of Crotalus durissus terrificus venom demonstrated the presence of a pre-synaptic neurotoxic effect $(29,40)$. Gallacci et al. (41), showed a neuromuscular junction effect of crotoxin, but our results indicate that this effect was not produced by gyroxin.

In contrast, several bothropic venoms have the capacity to block the in vitro neuromuscular transmission process, although the venoms of these snakes did not provoke clinical signs of neurotoxicity $(42,43)$.

Finally, future studies to better understand the gyroxin action mechanism should be performed. The biological effects of this enzyme appear to constitute a potential candidate in bioprospecting for new drugs.

\section{COPYRIGHT}

(C) CEVAP 2011

\section{SUBMISSION STATUS}

Received: June 24, 2010.

Accepted: October 26, 2010.

Abstract published online: November 5, 2010.

Full paper published online: February 28, 2011.

\section{CONFLICTS OF INTEREST}

There is no conflict.

\section{FINANCIAL SOURCE}

The State of São Paulo Research Foundation (FAPESP) provided the financial grants (process number 2007/05159-7).

\section{ETHICS COMMITTEE APPROVAL}

The present study was approved by the Ethics Committee on Animal Experimentation of the Botucatu Medical School, UNESP.

\section{CORRESPONDENCE TO}

RUI SEABRA FERREIRA JÚNIOR, Centro de Estudos de Venenos e Animais Peçonhentos, CEVAP-UNESP, Caixa Postal 577, Botucatu, 18618-000, SP, Brasil. Phone: +55 14381454446. Email: rseabra@cevap.org.br.

\section{REFERENCES}

1. Braud S, Bon C, Wisner A. Snake venom proteins acting on hemostasis. Biochimie. 2000;82(910):851-9.

2. Matsui T, Fujimura Y, Titani K. Snake venom proteases affecting hemostasis and thrombosis. Biochim Biophys Acta. 2000;1477(1-2):146-56.

3. Serrano SM, Maroun RC. Snake venom serine proteinases: sequence homology vs. substrate specificity, a paradox to be solved. Toxicon. 2005;45(8):1115-32.

4. Bjarnason JB, Fox JW. Hemorrhagic metalloproteinases from snake venoms. Pharmacol Ther. 1994;62(3):325-72.

5. Lesk AM, Fordham WD. Conservation and variability in the structures of serine proteinases of the chymotrypsin family. J Mol Biol. 1996;258(3):501-37.

6. Pirkle H. Thrombin-like enzymes from snake venoms: an updated inventory. Scientific and Standardization Committee's Registry of Exogenous Hemostatic Factors. Thromb Haemost. 1998;79(3):675-83.

7. Stocker K, Fisher H, Meier J. Thrombin-like snake venom proteinases. Toxicon.1982;20(1):265-73.

8. Raw I, Rocha MC, Esteves MI, Kamiguti AS. Isolation and characterization of a thrombinlike enzyme from the venom of Crotalus durissus terrificus. Braz J Med Biol Res. 1986;19(3):333-8.

9. Barrio A. Gyroxin, a new neurotoxin of Crotalus durissus terrificus venom. Acta Physiol Latinoamer. 1961;11(1):224.

10. Moraes JRE, Correa PHA, Camplesi AC, Moraes FR. Experimental use of fibrin glue derived from snake venom in non-pregnant canine uterus. J Venom Anim Toxins incl Trop Dis. 2004;10(2):133-43.

11. Leite CVS, Naresse LE, Arantes HL, Lopes AF, 
Thomazini-Santos IA, Giannini MJS, et al. An evaluation by rat colon anastomosis of the efficacy of fibrin glue derived from snake venom. J Venom Anim Toxins. 2000;6(2):180-93.

12. Ferraro GC, Moraes JRE, Shimano AC, Pereira GT, Moraes FR, Bueno de Camargo MH. Effect of snake venom derived fibrin glue on the tendon healing in dogs. Clinical and biomechanical study. J Venom Anim Toxins incl Trop Dis. 2005;11(3):261-74.

13. Laemmli UK. Cleavage of structural proteins during the assembly of the head of bacteriophage T4. Nature. 1970;227(5259):680-5.

14. Vesterberg O. Isoelectric focusing of proteins in polyacrylamide gels. Biochim Biophys Acta. 1972;257(1):11-9.

15. Edman P, Begg G. A protein sequentor. Eur J Biochem. 1967;1(1):80-91.

16. Altschul SF, Madden TL, Schäffer AA, Zhang J, Zhang Z, Miller W, et al. Gapped BLAST and PSI-BLAST: a new generation of protein database search programs. Nucleic Acids Res. 1997;25(17):3389-402.

17. Erlanger BF, Kokowsky N, Cohen W. The preparation and properties of two new chromogenic substrates of trypsin. Arch Biochem Biophys. 1961;95(1):271-8.

18. Theakston RD, Reid HA. Development of simple standard assay procedures for the characterization of snake venoms. Bull World Health Organ. 1983;61(6):949-56.

19. Barrabin H, Martiarena JL, Vidal JC, Barrio A. Isolation and characterization of gyroxin from Crotalus durissus terrificus venom. In: Rosemberg P. Toxins: animals, plant and microbial. New York: Pergamon Press; 1978. p. 113-33.

20. Bülbring E. Observations on the isolated phrenic nerve diaphragm preparation of the rat. $\mathrm{Br} \mathrm{J}$ Pharmacol Chemother. 1946;1(1):38-61.

21. Magalhães A, Da Fonseca BC, Diniz CR, Gilroy $J$, Richardson $M$. The complete amino acid sequence of a thrombin-like enzyme/gyroxin analogue from the venom of the bushmaster snake (Lachesis muta muta). FEBS Lett. 1993;329(12):116-20.

22. Burkhart W, Smith GF, Su JL, Parikh I, LeVine $\mathrm{H} 3 \mathrm{rd}$. Amino acid sequence determination of ancrod, the thrombin-like alpha-fibrinogenase from the venom of Akistrodon rhodostoma. FEBS Lett. 1992;297(3):297-301.

23. Henschen-Edman AH, Theodor I, Edwards BF, Pirkle H. Crotalase, a fibrinogen-clotting snake venom enzyme: primary structure and evidence for a fibrinogen recognition exosite different from thrombin. Thromb Haemost. 1999;81(1):81-6.

24. da Silva NJ, Aird SD, Seebart C, Kaiser II. A gyroxin analog from the bushmaster (Lachesis muta muta). Toxicon. 1989;27(7):763-71.

25. Alexander G, Grothusen J, Zepeda H, Schwartzman RJ. Gyroxin, a toxin from the venom of Crotalus durissus terrificus, is a thrombin-like enzyme. Toxicon. 1988;26(10):953-60.

26. Silveira AM, Magalhães A, Diniz CR, de Oliveira EB. Purification and properties of the thrombinlike enzyme from the venom of Lachesis muta muta. Int J Biochem. 1989;21(8):863-71.

27. Nascimento N. Estudo comparativo entre crotoxina nativa e irradiada. Aspectos bioquímicos, imunogênicos e farmacológicos [dissertation]. São Paulo: Instituto de Pesquisas Energéticas e Nucleares; 1991.

28. Takeda AK, Barbosa SFC, Costa LM, Adelino MGF. Fracionamento do veneno Crotalus durissus terrificus por cromatografia de exclusão molecular. Rev Inst Med Trop São Paulo. 1985;27(3):115-22.

29. Camillo MA, Arruda Paes PC, Troncone LR, Rogero JR. Gyroxin fails to modify in vitro release of labeled dopamine and acetylcholine from rat and mouse striate tissue. Toxicon. 2001;39(6):84353.

30. de Oliveira DG, Murakami MT, Cintra AC, Franco JJ, Sampaio SV, Arni RK. Functional and structural analysis of two fibrinogenactivating enzymes isolated from the venoms of Crotalus durissus terrificus and Crotalus durissus collilineatus. Acta Biochim Biophys Sin. 2009;41(1):21-9.

31. Markland Jr FS. Snake venom fibrinogenolytic and fibrinolytic enzymes: an updated inventory. Registry of exogenous hemostatic factors of the Scientific and Standardization Committee of the International Society on Thrombosis and Haemostasis. Thromb Haemost.1998;79(3):668-74.

32. Andrião-Escarso SH, Sampaio SV, Cunha OA, Marangoni S, Oliveira B, Giglio JR. Isolation and characterization of a new clotting factor from Bothrops jararacussu (jararacuçu) venom. Toxicon. 1997;35(7):1043-52.

33. Silva Jr FP, De-Simone SG. S1 subsite in snake venom thrombin-like enzymes: can S1 subsite lipophilicity be used to sort binding affinities of trypsin-like enzymes to small-molecule inhibitors? Bioorg Med Chem. 2004;12(10):257187.

34. Costa FL, Rodrigues RS, Izidoro LF, Menaldo DL, Hamaguchi A, Homsi-Brandeburgo MI, et al. Biochemical and functional properties of a thrombin-like enzyme isolated from Bothrops pauloensis snake venom. Toxicon. 2009;54(6):725-35. 
35. Cho SY, Hahn BS, Yang KY, Kim YS. Purification and characterization of calobin II, a second type of thrombin-like enzyme from Agkistrodon caliginosus (Korean viper). Toxicon. 2001;39(4):499-506.

36. Liu S, Sun MZ, Sun C, Zhao B, Greenaway FT, Zheng Q. A novel serine protease from the snake venom of Agkistrodon blomhoffi ussurensis. Toxicon. 2008;52(7):760-8.

37. Ruiz de Torrent RM, Bongiovanni B, Leiva LC, Evangelista de Duffard AM, Rodríguez JP, Acosta de Pérez OC, et al. Neurotoxicological effects of a thrombin-like enzyme isolated from Crotalus durissus terrificus venom (preliminary study). Toxicon. 2007;50(1):144-52.

38. Pérez AV, Rucavado A, Sanz L, Calvete JJ, Gutiérrez JM. Isolation and characterization of a serine proteinase with thrombin-like activity from the venom of the snake Bothrops asper. Braz J Med Biol Res. 2008;41(1):12-7.

39. Hodgson WC, Wickramaratna JC. In vitro neuromuscular activity of snake venoms. Clin
Exp Pharmacol Physiol. 2002;29(9):807-14.

40. Chang CC, Lee JD. Crotoxin, the neurotoxin of South American rattlesnake venom, is a presynaptic toxin acting like beta-bungarotoxin. Naunyn Schmiedebergs Arch Pharmacol. 1977;296(2):159-68.

41. Gallacci M, Nascimento N, Rogero JR, Vassilieff VS. Influence of temperature upon effects of crotoxin and gamma-irradiated crotoxin at rat neuromuscular transmission. Toxicol Lett. 2000;114(1-3):77-80.

42. GallacciM, Oliveira M,DalPai-Silva M,Cavalcante WL, Spencer PJ. Paralyzing and myotoxic effects of a recombinant bothropstoxin-I (BthTX-I) on mouse neuromuscular preparations. Exp Toxicol Pathol. 2006;57(3):239-45.

43. Ponce-Soto LA, Barros JC, Marangoni S, Hernandez S, Dal Belo CA, Corrado AP, et al. Neuromuscular activity of BaTX, a presynaptic basic PLA2 isolated from Bothrops alternatus snake venom. Comp Biochem Physiol C Toxicol Pharmacol. 2009;150(2):291-7. 